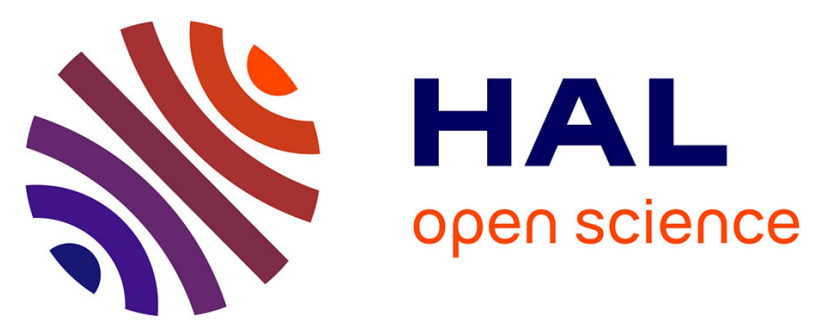

\title{
The effects of catalysts on the conversion of organic matter and bio-fuel production in the microwave pyrolysis of sludge at different temperatures
}

Rui Ma, Xiaofei Huang, Yang Zhou, Lin Fang, Shichang Sun, Peixin Zhang, Xianghua Zhang, Xuxin Zhao

\section{To cite this version:}

Rui Ma, Xiaofei Huang, Yang Zhou, Lin Fang, Shichang Sun, et al.. The effects of catalysts on the conversion of organic matter and bio-fuel production in the microwave pyrolysis of sludge at different temperatures. Bioresource Technology, 2017, 238, pp.616-623. 10.1016/j.biortech.2017.04.103 . hal01533329

HAL Id: hal-01533329

https://hal-univ-rennes1.archives-ouvertes.fr/hal-01533329

Submitted on 5 Jul 2017

HAL is a multi-disciplinary open access archive for the deposit and dissemination of scientific research documents, whether they are published or not. The documents may come from teaching and research institutions in France or abroad, or from public or private research centers.
L'archive ouverte pluridisciplinaire HAL, est destinée au dépôt et à la diffusion de documents scientifiques de niveau recherche, publiés ou non, émanant des établissements d'enseignement et de recherche français ou étrangers, des laboratoires publics ou privés. 
The Effects of Catalysts on the Conversion of Organic Matter and Bio-fuel Production in the Microwave Pyrolysis of Sludge at Different Temperatures

Rui Ma ${ }^{\mathrm{a}, \&}$, Xiaofei Huang ${ }^{\mathrm{a}}$, Yang Zhou ${ }^{\mathrm{a}}$, Lin Fang ${ }^{\mathrm{a}^{*}}$; Shichang Sun ${ }^{\mathrm{a}, \mathrm{b}, \mathrm{\&}^{*}} ;$ Peixin Zhang ${ }^{\mathrm{a}}$; Xianghua Zhang $^{\mathrm{c}, \mathrm{d}}$; Xuxin Zhao ${ }^{\mathrm{a}}$

\&: Rui Ma and Shichang Sun contributed equally to this work.

a College of Chemistry and Environmental Engineering, Shenzhen University, Shenzhen, 518060, China;

b College of Optoelectronic Engineering, Shenzhen University, Shenzhen, 518060, China;

c College of Physics and Energy, Shenzhen University, Shenzhen, 518060, China;

d Laboratory of Glasses and Ceramics, Institute of Chemical Science, University of Rennes 1, Rennes 35042, France.

ABSTRACT: Adding catalyst could improve the yields and qualities of bio-gas and bio-oil, and realize the oriented production. ${ }^{1}$ Results showed that the catalytic gas-production capacities of $\mathrm{CaO}$ were higher than those of $\mathrm{Fe}_{2} \mathrm{O}_{3}$, and the bio-gas yield at $800^{\circ} \mathrm{C}$ reached a maximum of $35.1 \%$. Because the polar cracking active sites of $\mathrm{CaO}$ reduced the activation energy of the pyrolysis reaction and resulted in high catalytic cracking efficiencies. In addition, the quality of bio-oil produced by $\mathrm{CaO}$ was superior to that by $\mathrm{Fe}_{2} \mathrm{O}_{3}$, although the bio-oil yield of $\mathrm{CaO}$ was relatively weak. The light bio-fuel

\footnotetext{
$1 *$ Corresponding author: email: fanglinhit@163.com;

*Co-corresponding author: sunshichang@ @zu.edu.cn

Full postal address: No. 3688, Nanhai Road, Nanshan District, Shenzhen, China, 518060.
} 
oriented catalytic pyrolysis could be realized when adding different catalysts. At $800^{\circ} \mathrm{C}$, $\mathrm{CaO}$ was $45 \%$ higher than $\mathrm{Fe}_{2} \mathrm{O}_{3}$ in aspect of $\mathrm{H}_{2}$ production while $\mathrm{Fe}_{2} \mathrm{O}_{3}$ was $103 \%$ higher than $\mathrm{CaO}$ in aspect of $\mathrm{CH}_{4}$ production. Therefore, $\mathrm{CaO}$ was more suitable for $\mathrm{H}_{2}$ production and $\mathrm{Fe}_{2} \mathrm{O}_{3}$ was more suitable for $\mathrm{CH}_{4}$ production.

Keywords: Catalytic microwave pyrolysis; $\mathrm{CaO}$ catalyst; $\mathrm{Fe}_{2} \mathrm{O}_{3}$ catalyst; $\mathrm{Bio}$-fuel; Sludge

\section{INTRODUCTION}

In recent years, with rapid economic development and urbanization, the treatment rates of industrial wastewater and domestic sewage have been gradually increasing, leading to a rapid surge in sludge production. Sludge has a high water content ( $>80 \%)$ (Zhao et al., 2010), a large volume and a complex composition. Besides containing a large amount of organic compounds, sludge contains heavy metals, pathogenic microorganisms, toxic and harmful substances, as well as other inorganic minerals (Namazi et al., 2015; Fonts et al., 2012). If sludge cannot be treated timely and effectively, it becomes a major pollution transfer, re-polluting the soil, water and even the food chain, and causes a considerable threat on the human body and the environment. Therefore, reducing the volume of sludge and its safe treatment and resource recovery are the hot spots of research. The utilization of municipal sludge has become the research focus and development trend of international sludge treatment and disposal.

Sludge pyrolysis is one of the effective ways to realize sludge utilization (Mohamed et al., 2016), it means that the macromolecular organic matter in the sludge is decomposed to produce gaseous, liquid and solid products in an inert environment. The gaseous products mainly include non-condensable small molecule gases, such as $\mathrm{H}_{2}$ and $\mathrm{CH}_{4}$, The liquid 
products contain bio-oil and pyrolytic water, and the solid products are the solid residues after pyrolysis. The resulting hydrogen and methane can be used as fuel gas, the bio-oil can be used as a raw material for liquid fuels or chemical reagents, and the solid residues can be used as adsorbents (Borges et al., 2014; Wang et al., 2016). Compared with traditional pyrolysis, microwave pyrolysis is more dominant because of its fast heating rate, high energy efficiency, and ease of operation and control (Huang et al., 2015). It can not only effectively realize the harmlessness, reducing and recycling of sludge, but also improve the quality and safety of the final products. As a result, microwave pyrolysis has become a hot topic of widespread concern.

Nevertheless, how to improve the production and quality of bio-gas and bio-oil generated from the sludge pyrolysis is still one of the most urgent problems to be solved (Deng et al., 2014). For example, the liquid phase products have a high water and oxygen content, a heat value half of that of the petroleum products, poor stability, and are difficult to be used as fuel. Furthermore, liquid phase products are acidic and sticky, and can adversely affect the normal operation of equipment. Meanwhile, sludge also contains a large number of $\mathrm{N}$ - and S-containing organic matters, resulting in a stimulant and in an unpleasant odor from the pyrolysates (Tian et al., 2014). Adding catalysts to the microwave pyrolysis of sludge seem to be a good solution to the above bottlenecks. Because adding catalysts can improve the efficiency of pyrolysis and the quality of pyrolysis steam, it is specifically to improve the quality of bio-oil and syngas (Beneroso et al., 2013). There are numerous types of catalysts for catalytic pyrolysis, the two most common are $\mathrm{CaO}$ and $\mathrm{Fe}_{2} \mathrm{O}_{3}$, which have been thoroughly used as the catalysts for different biomass in traditional pyrolysis and microwave pyrolysis because of their availability, low costs, and particular 
absorption characteristics. Due to its high deoxygenation efficiency and increased gas production, $\mathrm{CaO}$ exhibits a relatively high catalytic cracking efficiency (Zhang et al., 2014; Zhou et al., 2014; Fu et al., 2016). However, studies also showed that after a long period of high-temperature pyrolysis, carbon accumulates with $\mathrm{CaO}$, reducing its catalytic activity (Liu et al., 2016). $\mathrm{Fe}_{2} \mathrm{O}_{3}$ also has a good catalytic effect on the pyrolysis of biomass (Cho et al., 2012; Yu et al., 2014; Shang et al., 2015), $\mathrm{Fe}_{2} \mathrm{O}_{3}$ appears an effective deployment of the yield of biomass pyrolysis volatiles, including increasing the gas yield and reforming pyrolysis tar components, thereby increasing the relative content of light oil components to improve bio-oil quality. Nevertheless, most of the studies of catalytic pyrolysis are focused on the pyrolysis of coal and biomass (Lin et al., 2010; Veses et al., 2014; Fu et al., 2016), whose ingredient are much simpler than sludge. Quite few studies have been found concentrating on the pyrolysis of sludge catalyzed under microwave irradiation.

In order to improve the production and quality of bio-oil and bio-gas generated from microwave pyrolysis of sludge, $\mathrm{CaO}$ and $\mathrm{Fe}_{2} \mathrm{O}_{3}$ were selected as the catalysts in this study to explore their effect on the pyrolysis of sludge at different final pyrolysis temperatures, and further to investigate the effect on the conversion characteristics of organic matter, the production distribution, and the organic components of bio-oil and bio-gas. Combining with the analysis of the production mechanism of bio-oil and bio-gas, the optimization methods of bio-fuel production from microwave pyrolysis of sludge were proposed.

\section{MATERIALS AND METHODS}

\subsection{Experimental Materials}

The sludge sample used in this study was collected from the remaining sludge in the 
secondary sedimentation tank of a sewage treatment plant in Shenzhen, China. The sludge had a moisture content of $84.3 \%$, an ash content of $46.72 \%$, a volatile matter content of $50.42 \%$, and a fixed carbon content of $2.86 \%$. The raw sludge was analyzed by a Vario EL cube elemental analyzer, and the $\mathrm{C}, \mathrm{H}, \mathrm{N}$ and $\mathrm{S}$ contents are 28.86 wt.\%, 7.35 wt. \%, 3.88 wt. $\%$ and $0.89 \mathrm{wt} . \%$, respectively. In order to eliminate the interference of water on the analysis of the mechanism of $\mathrm{H}_{2}$ production from microwave pyrolysis of the biomass in sludge, the wet sludge was placed in an oven for drying at the temperature of $105^{\circ} \mathrm{C}$ for $12 \mathrm{~h}$. After drying, the dry sludge (DS) sample was ground using a mortar into a particle size of 1 $\mathrm{mm}$.

\subsection{Experimental Apparatuses and Methods}

The experimental device for microwave pyrolysis is shown in Figure 1, including a single-mode and linear adjustable microwave oven with a microwave frequency of $2450 \pm 50 \mathrm{MHz}$, a temperature control system and the product-collecting device. The product-collecting device consisted of a condensing device and a gas collector. A quartz reactor with a volume of $170 \mathrm{ml}$ was used as the microwave cavity, where a mixture of $30 \mathrm{~g}$ of pretreated sludge samples and $10 \mathrm{wt} . \%$ of catalyst was pyrolyzed each time. To ensure the inert reaction environment during the pyrolysis, high purity nitrogen gas was continuously introduced into the quartz reactor for 10 minutes at a flow rate of $200 \mathrm{~mL} / \mathrm{min}$ before the pyrolysis. After the microwave switch was turned on, the nitrogen flow rate was adjusted to $40 \mathrm{~mL} / \mathrm{min}$, and the retention time of the pyrolysis products in the quartz tube reactor was maintained as $255 \mathrm{~s}$. The power knob was adjusted according to the displayed temperature to maintain the final temperature of the pyrolysis at a constant. The 
high-temperature pyrolysis gas entered into the condensing device, and part of the gas was liquefied to oil, which was extracted with dichloromethane. The bio-oil was obtained after the removal of dichloromethane with a rotary evaporator. Non-condensable gases were collected using a 2-L air bag.

\subsection{Analysis of bio-oil and bio-gas}

The pyrolysis bio-oil was analyzed by a gas chromatography-mass spectrometry (GC-MS) system (Agilent, model GCMS-QP2010) and equipped with a DB-5MS column. The operating conditions were as follows: manual injection; injection volume: $1 \mathrm{~mL}$; initial temperature: $40^{\circ} \mathrm{C}$; inlet temperature: $250^{\circ} \mathrm{C}$; interface temperature: $270^{\circ} \mathrm{C}$; carrier gas: helium; and flow rate: $1.0 \mathrm{~mL} / \mathrm{min}$. The gaseous products from pyrolysis were determined by a gas chromatography system (FULI, type GC9790) with an external standard method. The chromatography system was equipped with a TXD-01 column with a sampling volume of $1 \mathrm{ml}$. The detector was a thermal conductivity detector (TCD), high purity $\mathrm{N}_{2}$ and $\mathrm{He}$ were used as the carrier gases, and the temperatures of the detector, the thermal conductivity cell, and the column oven were $120^{\circ} \mathrm{C}, 120^{\circ} \mathrm{C}$, and $70^{\circ} \mathrm{C}$, respectively.

The experimental data were statistically analyzed by SPSS13.0 data analysis software, the analysis results showed that the significance level $\mathrm{p}$ between two data sets was $\mathrm{p} \leqslant 0.05$, which indicated that the present datum in this work were useful.

\subsection{Calculations of component and yield of bio-oil and bio-gas}

2.4.1 The relative content of bio-oil component

The types of organics in the bio-oil were determined by referencing the data in the standard mass spectrometry database, and the relative content was analyzed by calculating 
the peak area in the total ion chromatogram.

Normalization method: Since the amount of component in the sample was proportional to the peak area, the corresponding peak was obtained according to the signal generated by the components in the sample. The conversion formula was as follows:

$$
\mathrm{W}=\left[\mathrm{A}_{\mathrm{i}} \mathrm{f}_{\mathrm{i}} /\left(\mathrm{A}_{1} \mathrm{f}_{1}+\mathrm{A}_{2} \mathrm{f}_{2}+\cdots+\mathrm{A}_{\mathrm{n}} \mathrm{f}_{\mathrm{n}}\right)\right] \times 100 \%
$$

Since the samples were bio-oil products and the correction factors were similar, the relative content of the component could be approximately calculated using the normalized peak area directly as follows:

$$
\mathrm{W}=\left[\mathrm{A}_{\mathrm{i}} /\left(\mathrm{A}_{1}+\mathrm{A}_{2}+\cdots+\mathrm{A}_{\mathrm{n}}\right)\right] \times 100 \%
$$

where A represented the peak area, f represented the correction factor, and $\mathrm{W}$ represented the relative content of the component.

2.4.2 The yield of the bio-gas components

The yield of each component of the bio-gas was calculated based on the mass of the gas produced per kilogram of dry sludge. First, the volume of each component was calculated by multiplying the amount of bio-gas with the volume content of each component, and then the volume $\mathrm{V}$ of the gas under the standard condition $\left(0^{\circ} \mathrm{C}, 101.325\right.$ $\mathrm{kPa}$ ) was calculated according to the ideal gas law PV $=$ nRT. Finally, the gas volume V was converted to the amount of gas per kilogram of dry sludge (unit: $\mathrm{L} / \mathrm{kg}$ ).

\subsubsection{The bio-gas production rate}

The relative content of each gaseous product (Ci) was obtained according to the results of the gas chromatography analysis using an external standard method, and then the volume of each gas and its production rate were calculated. The formula was as follows: 
Gas volume $\mathrm{V}_{\text {total }}=\left(\mathrm{V}_{1} \times \mathrm{C}_{1}+\mathrm{V}_{2} \times \mathrm{C}_{2}+\mathrm{V}_{3} \times \mathrm{C}_{3}+\ldots \ldots+\mathrm{V}_{\mathrm{n}} \times \mathrm{C}_{\mathrm{n}}\right)^{[\mathrm{a}]}$

Average gas production rate $=\mathrm{V}_{\text {total }} / \mathrm{T}^{[\mathrm{b}]}$

where $\mathrm{V}_{\mathrm{n}}$ was the volume of gas collected at each time period, and $\mathrm{T}$ was the total duration of pyrolysis.

\section{RESULTS AND DISCUSSION}

\subsection{Conversion of Organic Matter and Production Distribution}

With $\mathrm{CaO}$ and $\mathrm{Fe}_{2} \mathrm{O}_{3}$ as catalysts at $500-900^{\circ} \mathrm{C}$, the distribution of various products after microwave pyrolysis was shown in table 1 , and the conversion process of organic matter was shown in Figure 2. It was seen that the bio-char yields decreased at temperature from 500 to $900^{\circ} \mathrm{C}$, When $\mathrm{CaO}$ and $\mathrm{Fe}_{2} \mathrm{O}_{3}$ were used as catalysts, the bio-char yields at $900^{\circ} \mathrm{C}$ were $51 \%$ and $55.3 \%$ respectively, which were lower than that when catalysts were not added (60.4\%). Thus, $\mathrm{CaO}$ and $\mathrm{Fe}_{2} \mathrm{O}_{3}$ promoted the cracking of organic matter in the sludge. The existence of the catalysts caused the non-condensable gas generated by the pyrolysis to move between the catalyst particles, thus increasing the residence time, promoting the carbonation of the solid matter, the secondary thermal cracking of the organic matter and the pyrolysis reaction of the volatiles, and ultimately resulted in a more complete pyrolysis of the sludge (Liu et al., 2016). When $\mathrm{CaO}$ was used as catalyst, the bio-char yields became almost stable above $800^{\circ} \mathrm{C}$, which was the lowest in all conditions. Thus, the conversion of organic matter in sludge to organic oil or non-condensable gaseous products was achieved at $800^{\circ} \mathrm{C}$ with $\mathrm{CaO}$.

The bio-gas yields increased as the temperatures increased, especially adding catalyst $\mathrm{CaO}$ and $\mathrm{Fe}_{2} \mathrm{O}_{3}$ can improve the proportion of gaseous products significantly. At $800^{\circ} \mathrm{C}$ the 
bio-gas yield with $\mathrm{CaO}$ (stabilized to $35.1 \%$ ) was much higher than that of the raw sludge itself and adding $\mathrm{Fe}_{2} \mathrm{O}_{3}$, which increased by $132 \%$ and $45 \%$ respectively. Besides, Adding $\mathrm{CaO}$ as catalyst the yields of bio-char and bio-oil increased slightly, yet the bio-gas yield slightly decreased in the temperature range of $800-900^{\circ} \mathrm{C}$. It was inferred that $\mathrm{CaO}$ rapidly catalyzed the cracking of sludge at the temperature below $800^{\circ} \mathrm{C}$ due to the polar cracking active sites distributed on the surface and inside of $\mathrm{CaO}$, which reduced the activation energy of the pyrolysis reaction and resulted in high catalytic cracking efficiencies. When the temperature exceeds $800^{\circ} \mathrm{C}, \mathrm{CaO}$ was more easily adsorbed on the surface of the produced bio-char, resulting in decreased catalytic activity. Consequently, the solid residue yield showed a slight increase. Simultaneously, the short-chain gas molecules produced by thermal cracking reorganized on the surface of catalyst, and aromatization, alkylation, isomerization and other reactions occurred, resulting in a phenomenon that the bio-oil yield increase and bio-gas yield decrease slightly. Thus, $\mathrm{CaO}$ exhibited a relatively super catalytic effect in the conversion of organic matter during the microwave pyrolysis of sludge at $800^{\circ} \mathrm{C}$.

The bio-oil yield exhibited a downward trend after the initial increase as the temperatures rose when no catalyst and $\mathrm{Fe}_{2} \mathrm{O}_{3}$ was added, moreover the bio-oil yields both reached the maximum at $700^{\circ} \mathrm{C}$ were $18.4 \%$ and $20.4 \%$ respectively. An elevated temperature favored the devolatilization reaction, which was the main cause of the increased yield of bio-oil at relatively low temperatures (Loannidou et al., 2009). The bio-oil yields decreased at excessively high temperatures probably due to catalyst deactivation and secondary pyrolysis of the volatiles (Xie et al., 2014). In addition, the carbonization of volatile matter to produce bio-char was also another reason for a decrease 
in the yield of bio-oil. Combined with the change law that the gas yield slightly increased $\left(500-700^{\circ} \mathrm{C}\right)$ and significantly increased $\left(800-900^{\circ} \mathrm{C}\right)$, It was seen that the conversion of organic matter in sludge to oil products dominated at temperature from $500^{\circ} \mathrm{C}$ to $700^{\circ} \mathrm{C}$, however the conversion of organic matter to gaseous products played a leading role at temperature from $800^{\circ} \mathrm{C}$ to $900^{\circ} \mathrm{C}$. The oxygen-containing groups and the $\pi$ bonds in the unsaturated hydrocarbons were attracted by the empty d orbit of $\mathrm{Fe}_{2} \mathrm{O}_{3}$. This phenomenon resulted in the enhanced conversion efficiency of organic matter in the microwave pyrolysis of sludge when $\mathrm{Fe}_{2} \mathrm{O}_{3}$ was used as the catalyst.

\subsection{Analysis of Bio-Oil Composition and Production Mechanism}

The component composition of the bio-oil produced by the microwave pyrolysis of sludge was complex and could be grouped into aliphatic hydrocarbons, aromatic hydrocarbons, oxygen-containing aliphatic compounds, oxygen-containing aromatic compounds, nitrogen-containing aliphatic compounds, nitrogen-containing aromatic compounds and other undetected compounds. The effect of catalyst on the distribution of the organic component contents of the oil products at different final pyrolysis temperatures was shown in Figure 3.

Microwave pyrolysis gradually boosted the level of the aliphatic hydrocarbons as the temperature rose. Owing to the stronger interactions between the high frequency electromagnetic field of the microwave and the negatively charged $\pi$-electron system of the organic molecules with higher temperatures. The maximum content of the aliphatic hydrocarbons with $\mathrm{CaO}$ at $900^{\circ} \mathrm{C}$ was $15.77 \%$, which was $72 \%$ and $28 \%$ higher than no adding catalyst $(9.18 \%)$ and adding $\mathrm{Fe}_{2} \mathrm{O}_{3}$ catalyst (12.33\%), respectively. $\mathrm{CaO}$ exhibited a better catalytic effect on the pyrolysis of organic compounds during the microwave 
pyrolysis primarily due to the surface of $\mathrm{CaO}$ contained positively charged ions, and most organic molecules in bio-oil have negative $\pi$ electron systems. Therefore, in the pyrolysis process, the positive ions on the surface of $\mathrm{CaO}$ interacted with the organic molecules containing the $\pi$ electron system, which changed the stability of the molecular structure of the organics, reduced the activation energy of the cleavage of these organic compounds, and made the $\mathrm{C}-\mathrm{C}$ bond easier to break.

The aromatics yields reached the maximum at $800^{\circ} \mathrm{C}$ in all conditions, and the maximum yields was $16.73 \%$ when adding $\mathrm{CaO}$, which was $91 \%$ higher than not adding catalyst. Moreover, the average content of the oxygen-containing aromatics was $58 \%$ higher than no adding catalyst. Thus, $\mathrm{CaO}$ promoted the formation of the aromatic compounds significantly. It was because that $\mathrm{CaO}$ promoted the cleavage of large-molecule oligomers and produced low-molecular-weight stable aromatic compounds. In addition, the aromatic hydrocarbons contained a negative cyclic $\pi$ electron system that was attracted by the interaction between $\mathrm{Ca}^{2+}$ and $\mathrm{O}^{2-}$ (Ellig et al., 1985), reduced the stability of this system to the aromatic side chain cleavage and increased the yield of the aromatic hydrocarbons. The average content of the oxygen-containing aromatic compounds was $7.24 \%$ when adding $\mathrm{Fe}_{2} \mathrm{O}_{3}$, which was lower than other two conditions, indicating that $\mathrm{Fe}_{2} \mathrm{O}_{3}$ inhibited the formation of the aromatic compounds. Phenol is an important member of the oxygen-containing aromatic compounds, and its lowest content was obtained with $\mathrm{Fe}_{2} \mathrm{O}_{3}$. Under microwave induction, $\mathrm{Fe}_{2} \mathrm{O}_{3}$ catalyzed $\mathrm{OH} \bullet$ and $\mathrm{HO}_{2} \bullet$ free radicals produced during the microwave pyrolysis, occurred a series of reactions with phenol, thereby reducing the relative content of phenol.

A high oxygen content increases the viscosity and the flash point of the bio-oil, 
leading to a deterioration in its stability (Tian et al., 2011; Oasmaa et al., 2012). It also reduces the energy density of the oil products, and renders them unsuitable as energy sources. The oxygen content attained the lowest at $800^{\circ} \mathrm{C}$ under different conditions, the average content of the oxygen-containing aliphatic compound was $54.95 \%$ when not adding catalyst, which was higher than adding $\mathrm{CaO}(34.90 \%)$ and $\mathrm{Fe}_{2} \mathrm{O}_{3}$ (44.67\%), It was seen that $\mathrm{CaO}$ reduced the oxygen content significantly, thus achieved the deoxygenation of bio-oil. The similar conclusions were observed in some previous studies that reported that $\mathrm{CaO}$ had a significant deoxygenation on bio-oil (Lin et al., 2010; Li et al., 2012). Also, $\mathrm{Ca}^{2+}$ promoted the dehydration in the catalytic pyrolysis process, which was an important factor in reducing the oxygen content. During the microwave pyrolysis process, the positive ions on the surface of $\mathrm{CaO}$ interacted with the carboxylic acids organic molecules containing the negatively charged $\pi$ electron system, which changed the stability of the molecular structure of the organics, reduced the activation energy of the cleavage of these organic compounds, and reduced the bond energy between the oxygen-containing functional groups and the main chain, thus promoting the breakage of the oxygen-containing functional groups such as carboxyl group. The pyrolysis of Carboxylic acid compounds ( $\mathrm{RCOOH}$ ) by $\mathrm{CaO}$ catalytic microwave can be divided into two reaction pathways. One, under the microwave irradiation, $\mathrm{RH}$ and $\mathrm{CO}_{2}$ was produced directly from cracking. Second, with $\mathrm{CaO}$ catalyst, $(\mathrm{RCOO})_{2} \mathrm{Ca}$ the organic calcium salt of carboxylic acid was produced after the dehydrogenation and dehydration, thus carboxyl oxygen groups were fixed in the form of the organic calcium salts, and ( $\mathrm{RCOO})_{2} \mathrm{Ca}$ during the high temperature microwave pyrolysis continued to crack and produced $\mathrm{CaCO}_{3}$ and the ketone functional compounds (RCOR), while $\mathrm{CaCO}_{3}$ can decompose to produce $\mathrm{CaO}$ and $\mathrm{CO}_{2}$, and the $\mathrm{CaO}$ production 
can be recycled to be used as catalyst again. Besides, the interaction between $\mathrm{Ca}^{2+}$ and $\mathrm{O}^{2-}$ both attracted and activated the oxygen-containing groups, thus interfering the electron-cloud trajectory of carbon-oxygen double bond, and achieving deoxygenation.

When the contents of the aromatic hydrocarbons and the aliphatic hydrocarbons were higher in the bio-oil, the oxygen content was lower, thus the quality of bio-oil was better, and the bio-oil was a superior raw material for use as fuel energy or valuable chemical products. The contents of the aliphatic hydrocarbons and the aromatic hydrocarbons when adding $\mathrm{CaO}$ at $800^{\circ} \mathrm{C}$ were $12.02 \%$ and $16.73 \%$, respectively, and the average content of the oxygen-containing aliphatic compounds was as low as $34.9 \%$. In summary, $800^{\circ} \mathrm{C}$ is considered to be the optimum temperature and adding $\mathrm{CaO}$ catalyst for improving the bio-oil quality significantly.

\subsection{Analysis of Bio-gas Production and Process Optimization}

$\mathrm{H}_{2}$ and $\mathrm{CH}_{4}$ are the main gas components (>80\%) produced from the microwave pyrolysis of sludge. The effects of $\mathrm{CaO}$ and $\mathrm{Fe}_{2} \mathrm{O}_{3}$ as catalysts on the production of $\mathrm{H}_{2}$ and $\mathrm{CH}_{4}$ at different temperature are shown in Figure 4. The results indicated that as the temperature increases, the $\mathrm{CaO}$ and $\mathrm{Fe}_{2} \mathrm{O}_{3}$ catalysts improve the gas production of $\mathrm{H}_{2}$ and $\mathrm{CH}_{4}$ significantly, compared to the absence of catalyst. Adding catalyst reduced the activation energy of the pyrolysis reaction effectively, thereby reducing temperature required for the reaction. During the pyrolysis of sludge, a higher temperature led to a faster heating rate and a shorter gas residence time in the reactor, although the gas residence time was more influenced by the sweep gas flow rate. Additionally, an increase in temperature promoted the secondary cleavage of volatiles, which was conducive to the production of $\mathrm{H}_{2}$, 
$\mathrm{CH}_{4}$ and other small-molecule gases. The resulting pyrolysis gas had a higher calorific value and a better combustion performance, and the mass generated of $\mathrm{H}_{2}$ and $\mathrm{CH}_{4}$ also increased the recycling value of the sludge pyrolysis gas as fuel (Domínguez et al., 2006).

The total production of $\mathrm{H}_{2}$ and $\mathrm{CH}_{4}$ rose with increasing temperatures and reached the maximum at $900^{\circ} \mathrm{C}$ under different catalytic conditions, at this moment, the maximum total production of $\mathrm{H}_{2}$ and $\mathrm{CH}_{4}$ with $\mathrm{CaO}(46.39 \mathrm{~L} / \mathrm{kg})$ and $\mathrm{Fe}_{2} \mathrm{O}_{3}(45.46 \mathrm{~L} / \mathrm{kg})$ was $87 \%$ and $83 \%$ higher than not adding catalyst, respectively. At $800^{\circ} \mathrm{C}$, the fuel gas production with $\mathrm{CaO}$ and $\mathrm{Fe}_{2} \mathrm{O}_{3}$ improved $105 \%$ and $84 \%$ respectively, compared to the addition of no catalyst. This shows the addition of $\mathrm{CaO}$ and $\mathrm{Fe}_{2} \mathrm{O}_{3}$ catalysts improved the efficiency of the fuel gas production significantly, and $800^{\circ} \mathrm{C}$ was the optimum temperature for producing $\mathrm{H}_{2}$ and $\mathrm{CH}_{4}$ high quality gas.

$\mathrm{H}_{2}$ production also increased with increasing temperatures, tended to stabilize (15.4 $\mathrm{L} / \mathrm{kg})$ above $700^{\circ} \mathrm{C}$ without catalysts. $\mathrm{H}_{2}$ production reached the maximum $(29.56 \mathrm{~L} / \mathrm{kg})$ at $900^{\circ} \mathrm{C}$ with $\mathrm{Fe}_{2} \mathrm{O}_{3}$, was $92 \%$ higher than that with no catalyst. Adding $\mathrm{CaO}$ as the catalyst, the $\mathrm{H}_{2}$ production $\left(38.56 \mathrm{~L} / \mathrm{kg}\right.$ ) stabilized at $800^{\circ} \mathrm{C}$ and increased by $162 \%$ than no adding catalyst, the effect of $\mathrm{CaO}$ on enhancing the $\mathrm{H}_{2}$ production was more splendid than that of $\mathrm{Fe}_{2} \mathrm{O}_{3}$. Adding $\mathrm{CaO}$, the $\mathrm{H}_{2}$ production at $900^{\circ} \mathrm{C}$ was slightly lower than that at $800^{\circ} \mathrm{C}$, which was directly related to the increase in the reaction rate and the gas outflowing rate at $900^{\circ} \mathrm{C}$ higher temperature. The highest hydrogen production rate occurred (Figure 5) with $\mathrm{CaO}$ catalyst at $900^{\circ} \mathrm{C}$, the residence time of the pyrolysis gas in the microwave environment shortened, the probability of water gasification reaction reduced, and resulted in the reduction of $\mathrm{H}_{2}$ production. Based on the above findings, $\mathrm{CaO}$ exhibited a superior catalytic effect on hydrogen production at $800^{\circ} \mathrm{C}$, and an apparent advantage in promoting 
$\mathrm{H}_{2}$ production, which was consistent with Ying Yu's conclusion that $\mathrm{CaO}$ favored the $\mathrm{H}_{2}$ production via catalytic pyrolysis (Yu et al., 2014).

$\mathrm{CH}_{4}$ is generally formed by the breakage of aliphatic side chains in the organics at low temperatures. As the pyrolysis temperature rose, the oil products occurred a secondary cracking reaction at high temperatures and continued to produce $\mathrm{CH}_{4}$ and other small-molecule substances, which caused an increase in $\mathrm{CH}_{4}$ production with increasing temperatures. $\mathrm{CaO}$ reacted with $\mathrm{CH}_{4}$ to generate $\mathrm{CH}_{3} \mathrm{OH}$ while serving as the catalyst (Lin et al., 2009), so the $\mathrm{CH}_{4}$ production with $\mathrm{CaO}$ was lower than that with no catalyst above $500^{\circ} \mathrm{C}$. The catalytic effect of $\mathrm{Fe}_{2} \mathrm{O}_{3}$ on the $\mathrm{CH}_{4}$ production was significant. $\mathrm{CH}_{4}$ production with $\mathrm{Fe}_{2} \mathrm{O}_{3}(14.6 \mathrm{~L} / \mathrm{kg})$ was $92 \%$ higher than that without catalyst at $800^{\circ} \mathrm{C}$. At $900^{\circ} \mathrm{C}$, the $\mathrm{CH}_{4}$ production under different catalytic conditions all reached their peak values. The maximum $\mathrm{CH}_{4}$ production with $\mathrm{Fe}_{2} \mathrm{O}_{3}(15.9 \mathrm{~L} / \mathrm{kg})$ increased by $60 \%$ than that without catalyst $(9.9 \mathrm{~L} / \mathrm{kg})$. Therefore, $\mathrm{Fe}_{2} \mathrm{O}_{3}$ exhibited a strong catalytic effect on $\mathrm{CH}_{4}$ production when temperature above $800^{\circ} \mathrm{C}$, especially the most significant upgrade efficiency occurred at $800^{\circ} \mathrm{C}$.

The effects of different catalysts on the $\mathrm{H}_{2}$ and $\mathrm{CH}_{4}$ production processes at different final pyrolysis temperatures were further analyzed, and the results were shown in Figure 5. The $\mathrm{H}_{2}$ and $\mathrm{CH}_{4}$ production rates trended downward over time after their initial increase, and the rates of production for both gases increased sharply at about 2 minutes. $\mathrm{The} \mathrm{H}_{2}$ and $\mathrm{CH}_{4}$ production rates rose with increasing temperatures, reached maximum at $900^{\circ} \mathrm{C}$. The $\mathrm{H}_{2}$ production rates at the different pyrolysis final temperatures were higher than the corresponding $\mathrm{CH}_{4}$ production rates, and the duration of the $\mathrm{H}_{2}$ production rate was longer than that of $\mathrm{CH}_{4}$ production rate, which resulted in the $\mathrm{H}_{2}$ production to be greater than the 
$\mathrm{CH}_{4}$ production.

The law of changes in the $\mathrm{H}_{2}$ production rate with $\mathrm{Fe}_{2} \mathrm{O}_{3}$ showed similar trends with those no catalyst added, and reached the maximum production rate within 3 minutes. In the last stage, the rate of gas production decreased sharply, and $\mathrm{H}_{2}$ stopped producing at 20 minutes. The maximum production rates with $\mathrm{CaO}$ were reached after 10 minutes of pyrolysis at $500^{\circ} \mathrm{C}, 600^{\circ} \mathrm{C}$ and $800^{\circ} \mathrm{C}$, those were reached within 5 minutes at $700^{\circ} \mathrm{C}$ and $900^{\circ} \mathrm{C}$, and $\mathrm{H}_{2}$ production stopped at about 35 minutes. The maximum $\mathrm{H}_{2}$ production rates with $\mathrm{CaO}(134 \mathrm{~mL} / \mathrm{min})$ and $\mathrm{Fe}_{2} \mathrm{O}_{3}(128 \mathrm{~mL} / \mathrm{min})$ at $900^{\circ} \mathrm{C}$ improved by $23 \%$ and $17.4 \%$ than those without catalysts $\left(109 \mathrm{~mL} / \mathrm{min}\right.$ ), respectively. At $800^{\circ} \mathrm{C}, \mathrm{CaO}$ (increasing by $50 \%$ ) was more conducive to catalytic hydrogen production than $\mathrm{Fe}_{2} \mathrm{O}_{3}$ (increasing by $35 \%$ ), and the increase in the $\mathrm{H}_{2}$ production rate at $800^{\circ} \mathrm{C}$ was greater than that at $900^{\circ} \mathrm{C}$. At different temperatures, the duration of high $\mathrm{H}_{2}$ generation rate ( $>20 \mathrm{~mL} / \mathrm{min}$ ) with $\mathrm{CaO}$ was the longest, followed by $\mathrm{Fe}_{2} \mathrm{O}_{3}$ and no catalyst. At $800^{\circ} \mathrm{C}$, the duration of hydrogen generation rate adding $\mathrm{CaO}$ ( 25 minutes) increased by 17 minutes compared with $\mathrm{Fe}_{2} \mathrm{O}_{3}$. $\mathrm{CaO} 、 \mathrm{Fe}_{2} \mathrm{O}_{3}$ catalyst increased the $\mathrm{H}_{2}$ production rate and prolonged the duration of high $\mathrm{H}_{2}$ production rate, thereby enhancing $\mathrm{H}_{2}$ production, and $\mathrm{CaO}$ was more suitable for $\mathrm{H}_{2}$ production. Because $\mathrm{CaO}$ was easier to reduce the reaction activation energy of the cracking of long-chain hydrocarbons, which allowed polymerization, cyclization and aromatization to easily proceed.

Compared with the $\mathrm{H}_{2}$ production, the $\mathrm{CH}_{4}$ production rate all reached the maximum within 3 minutes, stopped producing at 15 minutes, and the duration for $\mathrm{CH}_{4}$ production was relatively short. $\mathrm{Fe}_{2} \mathrm{O}_{3}$ provided the highest $\mathrm{CH}_{4}$ production rate, followed by no 
catalyst and $\mathrm{CaO}, \mathrm{CH}_{4}$ production rate with $\mathrm{Fe}_{2} \mathrm{O}_{3}$ was affected little between $500-700^{\circ} \mathrm{C}$, but significantly increased at $800-900^{\circ} \mathrm{C}$ until reached the maximum value of $89 \mathrm{~mL} / \mathrm{min}$, which was $71 \%$ higher than that without adding catalysts. At $800^{\circ} \mathrm{C}$, the maximum $\mathrm{CH}_{4}$ production rate increased by $81 \%$ than that without catalyst, so the improve performance was better than that at $900^{\circ} \mathrm{C}$. The duration of high $\mathrm{CH}_{4}$ production rate $(>10 \mathrm{~mL} / \mathrm{min})$ with $\mathrm{Fe}_{2} \mathrm{O}_{3}$ was significantly longer than $\mathrm{CaO}$ and without a catalyst, the duration of high $\mathrm{CH}_{4}$ production rate with $\mathrm{Fe}_{2} \mathrm{O}_{3}$ (8 minutes) increased by 5 minutes compared with $\mathrm{CaO}$ at $800^{\circ} \mathrm{C}$. Therefore, the increase in the $\mathrm{CH}_{4}$ production rate and the prolongation of the duration of a high $\mathrm{CH}_{4}$ production rate were the important factors for the increased $\mathrm{CH}_{4}$ production by adding $\mathrm{Fe}_{2} \mathrm{O}_{3}$ catalyst. $\mathrm{Fe}_{2} \mathrm{O}_{3}$ promoted the decomposition and hydrogenation of the methyl side chain, so that the reaction easily advanced. However, while acting as a catalyst, $\mathrm{CaO}$ also reacted with $\mathrm{CH}_{4}$ to produce $\mathrm{CH}_{3} \mathrm{OH}$ (Yu et al., 2014). Therefore, $\mathrm{Fe}_{2} \mathrm{O}_{3}$ had a better enhancing effect on the rate of $\mathrm{CH}_{4}$ production than $\mathrm{CaO}$.

\section{CONCLUSIONS}

Adding catalyst to the microwave pyrolysis system could improve the yields and qualities of the bio-gas and bio-oil and realize the oriented production, which provided a possibility for the microwave pyrolysis technology in application of sludge recycling. $\mathrm{CaO}$ was a better catalyst for the production of bio-gas while $\mathrm{Fe}_{2} \mathrm{O}_{3}$ was better for bio-oil. The best quality of bio-oil could be realized at $800^{\circ} \mathrm{C}$ when catalyzed by $\mathrm{CaO}$, while the maximum bio-gas production could both be catalyzed by $\mathrm{CaO}$ and $\mathrm{Fe}_{2} \mathrm{O}_{3}$ at $900^{\circ} \mathrm{C}$. $\mathrm{CaO}$ was suitable for oriented catalytic production of $\mathrm{H}_{2}$ while $\mathrm{Fe}_{2} \mathrm{O}_{3}$ was preferred for $\mathrm{CH}_{4}$ production. 


\section{Acknowledgements}

This paper was supported by the China National Natural Science Foundation (50906058), the Natural Science Foundation of SZU (No. 827-000037), and the Shenzhen Science and Technology Planning Project (Grant Nos. JCYJ20150828113927076, JCYJ20130329113322731).

\section{References}

[1] Beneroso, D., Bermúdez, J. M., Arenillas, A., Menéndez, J. A., 2013. Microwave pyrolysis of microalgae for high syngas production. Bioresource Technol. 144, 240-246.

[2] Borges, F. C., Du, Z., Xie, Q., Trierweiler, J.O., Cheng, Y., Wan, Y., Liu Y., Zhu R., Lin, X., Chen, P., Ruan, R., 2014. Fast microwave assisted pyrolysis of biomass using microwave absorbent. Bioresource Technol. 156, 267-274.

[3] Cho, W., Kim, S., Choi, H., Rhim, Y., Lim, J., Lee, S., Yoo, J., 2012. Characterization of chars made of solvent extracted coals. Korean J. Chem. Eng. 29, 190-195.

[4] Deng, W., Su, Y., Liu, S., Shen, H., 2014. Microwave-assisted methane decomposition over pyrolysis residue of sewage sludge for hydrogen production. Int. J. Hydrogen Energ. 39, 9169-9179.

[5] Dominguez, A., Menendez, J. A., Inguanzo, M., Pis, J.J., 2006. Production of bio-fuels by high temperature pyrolysis of sewage sludge using conventional and microwave heating. Bioresource Technol. 97, 1185-1193.

[6] Dominguez, A., Menendez, J. A., Pis, J. J., 2006. Hydrogen rich fuel gas production from the pyrolysis of wet sewage sludge at high temperature. J. Anal. Appl. Pyrol. 77, $127-132$ 
[7] Ellig, D. L., Lai, C. K., Mead, D. W., Longwell, J.P., Peters W.A., 1985. Pyrolysis of volatile aromatic hydrocarbons and n-heptane over calcium oxide and quartz. Ind. Eng. Chem. Process Des. Dev. 24, 1080-1087.

[8] Fonts, I., Gea, G., Azuara, M.,Ábrego, J., Arauzo, J., 2012. Sewage sludge pyrolysis for liquid production: A review. Renew. Sust. Energ. Rev. 16, 2781-2805.

[9] Fu, Y., Guo, Y., Zhang, K., 2016. Effect of three different catalysts ( $\mathrm{KCl}, \mathrm{CaO}$, and $\mathrm{Fe}_{2} \mathrm{O}_{3}$ ) on the reactivity and mechanism of low-rank coal pyrolysis. Energ. Fuel. 30, 2428-2433.

[10] Huang, Y., Shih, C., Chiueh, P., Shanglien, L., 2015. Microwave co-pyrolysis of sewage sludge and rice straw. Energy 87, 638-644.

[11] Loannidou, O., Zabaniotou, A., Antonakou, E. V., Papazisi, K. M., Lappas, A. A., Athanassiou, C., 2009. Investigating the potential for energy, fuel, materialsand chemicals production from corn residues (cobs and stalks) by non-catalyticand catalytic pyrolysis in two reactor configurations. Renew. Sust. Energ. Rev. 13, $750-762$

[12] Lin, Y.Y., Zhang, C., Zhang, M., Zhang, J., 2010. Deoxygenation of bio-oil during pyrolysis of biomass in the presence of $\mathrm{CaO}$ in a fluidized-bed reactor. Energ. Fuel. 24, 5686-5695.

[13] Lin, S., Wang, Y., Suzuki, Y., 2009. High-temperature $\mathrm{CaO}$ hydration/Ca(OH) decomposition over a multitude of cycles. Energ. Fuel. 23, 2855-2861.

[14] Li, X., Xu, F., Wang, J., 2010. Preparation of Fe-Cu catalysts and treatment of a wasterwater mixture by microwave-assisted UV catalytic oxidation processes. Environ. Technol. 31, 433-U110. 
[15] Li, R., Zhong, Z.P., Jin, B.S., Zheng, A. J., 2012. Application of mineral bed materialsduring fast pyrolysis of rice husk to improve water-soluble organics production. Bioresource Technol. 119, 324-330.

[16] Liu, H., Yi, L., Zhang, Q., Hu, H., Lu, G., Li, A., Yao, H., 2016. Co-production of clean syngas and ash adsorpbent during sewage sludge gasification: synergistic effect of fenton peroxidation and $\mathrm{CaO}$ conditioning. Appl. Energ. 179, 1062-1068.

[17] Liu, S. Y., Xie, Q. L., Zhang, B., Cheng, Y.L., Liu, Y.H., 2016. Fast microwave-assisted catalytic co-pyrolysis of corn stover and scum for bio-oil production with $\mathrm{CaO}$ and HZSM-5 as the catalyst. Bioresource Technol. 204, 164-170.

[18] Mohamed, B. A., Kim, C. S., Ellis, N., Bi, X., 2016. Microwave-assisted catalytic pyrolysis of switchgrass for improving bio-oil and biochar properties. Bioresource Technol. 201,121-132.

[19] Namazi, A. B., Grant, A. D., Jia, C. Q., 2015. Microwave-assisted pyrolysis and activation of pulp mill sludge. Biomass Bioenerg. 73, 217-224.

[20] Oasmaa, A., Kuoppala, E., Elliott, D.C., 2012. Development of the Basis for an Analytical Protocol for Feeds and Products of Bio-oil Hydrotreatment. Energ. Fuel. 26, $2454-2460$.

[21] Shang, H., Lu, R., Shang, L., Zhang, W. H., 2015. Effect of additives on the microwave-assisted pyrolysis of sawdust. Fuel Process. Technol. 131,167-174.

[22] Tian, Y., Zuo, W., Ren, Z., Chen, D., 2011. Estimation of a novel method to produce bio-oil from sewage sludge by microwave pyrolysis with the consideration of efficiency and safety. Bioresource technol. 102, 2053-2061.

[23] Tian, Y., Zuo, W., Chen, D., 2011. Crystallization evolution, microstructure and 
properties of sewage sludge-based glass-ceramics prepared by microwave heating. J. Hazard. Mater. 196, 370-379.

[24] Tian, K., Liu, W. J., Qian, T. T., Jiang, H., Yu, H. Q., 2014. Investigation on the evolution of $\mathrm{N}$-containing organic compounds during pyrolysis of sewage sludge. Environ. Sci. Technol. 48, 10888-10896.

[25] Veses, A., Aznar, M., Martínez, I., Martíneza, J. D., López, J. M., Navarro, M. V., Callén, M. S., Murillo, R., García, T., 2014. Catalytic pyrolysis of wood biomass in an augerreactor using calcium-based catalysts. Bioresource Technol. 162, 250-258.

[26] Yawei, W., Chengmin, G., Xiaotang, N., Meixue, C., Yuansong, W., 2015. Multivariate analysis of sludge disintegration by microwave-hydrogen peroxide pretreatment process. J. Hazard. Mater. 283, 856-864.

[27] Wang, Y., Xiao, Q., Zhong, H., Zheng, X., Wei, Y., 2016. Effect of organic matter on phosphorus recovery from sewage sludge subjected to microwave hybrid pretreatment. J. Environ. Sci.-China, 39, 29-36.

[28] Xu, G.R., Zou, J.L., Li, G.B., 2009. Ceramsite obtained from water and wastewater sludge and its characteristics affected by $\left(\mathrm{Fe}_{2} \mathrm{O}_{3}+\mathrm{CaO}+\mathrm{MgO}\right) /\left(\mathrm{SiO}_{2}+\mathrm{Al}_{2} \mathrm{O}_{3}\right)$. Water Resear. 43, 2885-2893.

[29] Xie, Q., Peng, P., Liu, S., Min, M., Cheng, Y., Wan, Y., Li, Y., Lin, X., Liu, Y., Chen, P., Ruan, R., 2014. Fast microwave-assisted catalytic pyrolysis of sewage sludge for bio-oil production. Bioresource Technol. 172, 162-168.

[30] Yu, Y., Yu, J., Sun, B., Yan, Z., 2014. Influence of catalyst types on the microwave-induced pyrolysis of sewage sludge. J. Anal. Appl. Pyrol. 106, 86-91.

[31] Zhao, L., Gu, W., He, P., Shao, L., 2010. Effect of air-flow rate and turning frequency 
on bio-drying of dewatered sludge. Wat. Res. 44, 6144-6152.

[32] Zhou, C., Stuermer, T., Gunarathne, R., Yang W., Blasiak, W., 2014. Effect of calcium oxide on high-temperature steam gasification of municipal solid waste. Fuel 122, 36-46.Zhang, L., Zhang, B., Yang, Z., Yan, Y., 2014. Pyrolysis behavior of biomass with different Ca-based additives. Rsc Adv. 4, 39145-39155. 


\section{Figure Captions:}

Table.1. Production distribution in the microwave pyrolysis of sludge under different temperature (no catalyst, 10 wt. $\% \mathrm{CaO}, 10$ wt. $\% \mathrm{Fe}_{2} \mathrm{O}_{3}$ )

Fig.1. The experimental reaction device of microwave pyrolysis sludge.

1-Temperature indicator; 2-Ammeter;3-Thepoweradjustingknob;4-Operating interface;

5-Microwavetransmitter; 6-Quartzreactor; 7-waveguide; 8-magnetron; 9-PC with fuzzy logic algorithm; 10-Gas flow meter; 11-condenser pipe; 12-Tar products collection unit; 13-Heavy metals in the gas collection device; and 14-Air pocket.

Fig.2. The distribution of various products and the transformation mode of organic matter during the microwave pyrolysis.

Fig.3. The distribution curve of organic matter in bio oil under different catalysts: (a) no catalyst; (b) $\mathrm{CaO}$; and (c) $\mathrm{Fe}_{2} \mathrm{O}_{3}$.

Fig.4. Effects of catalysts on the gas production at different final pyrolysis temperatures: (a) $\mathrm{H}_{2}$; (b) $\mathrm{CH}_{4}$; and (c) $\mathrm{H}_{2}+\mathrm{CH}_{4}$.

Fig.5. Effects of catalysts on $\mathrm{H}_{2}$ and $\mathrm{CH}_{4}$ production rate at different final pyrolysis temperatures: ( $\mathrm{H}_{2}$ : (a) no catalyst, (b) $\mathrm{CaO}$, (c) $\mathrm{Fe}_{2} \mathrm{O}_{3} ; \mathrm{CH}_{4}$ : (d) no catalyst, (e) $\mathrm{CaO}$, (f) $\mathrm{Fe}_{2} \mathrm{O}_{3}$.) 
Table1

\begin{tabular}{llllll}
\hline Additive & $\begin{array}{l}\text { Temperature } \\
\left({ }^{\circ} \mathrm{C}\right)\end{array}$ & $\begin{array}{l}\text { Bio-char } \\
(\%)\end{array}$ & $\begin{array}{l}\text { Bio-oil } \\
(\%)\end{array}$ & $\begin{array}{l}\text { Pyrolysis water } \\
(\%)\end{array}$ & $\begin{array}{l}\text { Bio-gas } \\
(\%)\end{array}$ \\
\hline no catalyst & 500 & $70.0 \pm 3.4$ & $14.5 \pm 0.7$ & $4.2 \pm 0.2$ & $11.3 \pm 0.6$ \\
& 600 & $70.2 \pm 3.0$ & $15.4 \pm 0.8$ & $4.4 \pm 0.2$ & $10.0 \pm 0.5$ \\
& 700 & $68.0 \pm 3.1$ & $18.4 \pm 0.7$ & $3.2 \pm 0.1$ & $10.4 \pm 0.5$ \\
& 800 & $65.0 \pm 2.8$ & $16.5 \pm 0.7$ & $3.4 \pm 0.1$ & $15.1 \pm 0.7$ \\
& 900 & $60.0 \pm 2.0$ & $14.4 \pm 0.5$ & $2.1 \pm 0.1$ & $23.5 \pm 1.1$ \\
$\mathrm{CaO}$ & 500 & $65.2 \pm 2.7$ & $15.5 \pm 0.7$ & $2.2 \pm 0.1$ & $17.1 \pm 0.8$ \\
& 600 & $60.2 \pm 1.6$ & $14.4 \pm 0.6$ & $2.4 \pm 0.2$ & $23.0 \pm 1.2$ \\
& 700 & $55.0 \pm 2.0$ & $12.4 \pm 0.6$ & $1.2 \pm 0.1$ & $31.4 \pm 1.6$ \\
& 800 & $50.0 \pm 1.9$ & $13.5 \pm 0.7$ & $1.1 \pm 0.1$ & $35.1 \pm 2.0$ \\
& 900 & $51.0 \pm 0.8$ & $15.8 \pm 0.6$ & $1.1 \pm 0.1$ & $33.1 \pm 1.6$ \\
$\mathrm{Fe}_{2} \mathrm{O}_{3}$ & 500 & $70.2 \pm 2.9$ & $11.5 \pm 0.5$ & $3.2 \pm 0.2$ & $15.1 \pm 0.7$ \\
& 600 & $66.2 \pm 2.0$ & $16.4 \pm 0.8$ & $2.4 \pm 0.1$ & $15.0 \pm 0.7$ \\
& 700 & $60.0 \pm 2.8$ & $20.4 \pm 1.1$ & $2.2 \pm 0.1$ & $17.4 \pm 0.9$ \\
& 800 & $58.0 \pm 2.0$ & $16.5 \pm 0.7$ & $1.4 \pm 0.1$ & $24.1 \pm 1.1$ \\
& 900 & $55.0 \pm 1.4$ & $14.4 \pm 0.6$ & $1.1 \pm 0.1$ & $29.5 \pm 0.8$ \\
\hline
\end{tabular}

$(\mathrm{P} \leqslant 0.05)$ 


\section{Highlights:}

1. $\mathrm{CaO}$ was a better catalyst for the production of bio-gas while $\mathrm{Fe}_{2} \mathrm{O}_{3}$ for bio-oil.

2. The best quality of bio-oil could be catalyzed by $\mathrm{CaO}$ at $800^{\circ} \mathrm{C}$.

3. The maximum bio-gas production could both be catalyzed by $\mathrm{CaO}$ and $\mathrm{Fe}_{2} \mathrm{O}_{3}$ at $900^{\circ} \mathrm{C}$.

4. $\mathrm{CaO}$ was more suitable for oriented catalytic production of $\mathrm{H}_{2}$ while $\mathrm{Fe}_{2} \mathrm{O}_{3}$ for $\mathrm{CH}_{4}$. 


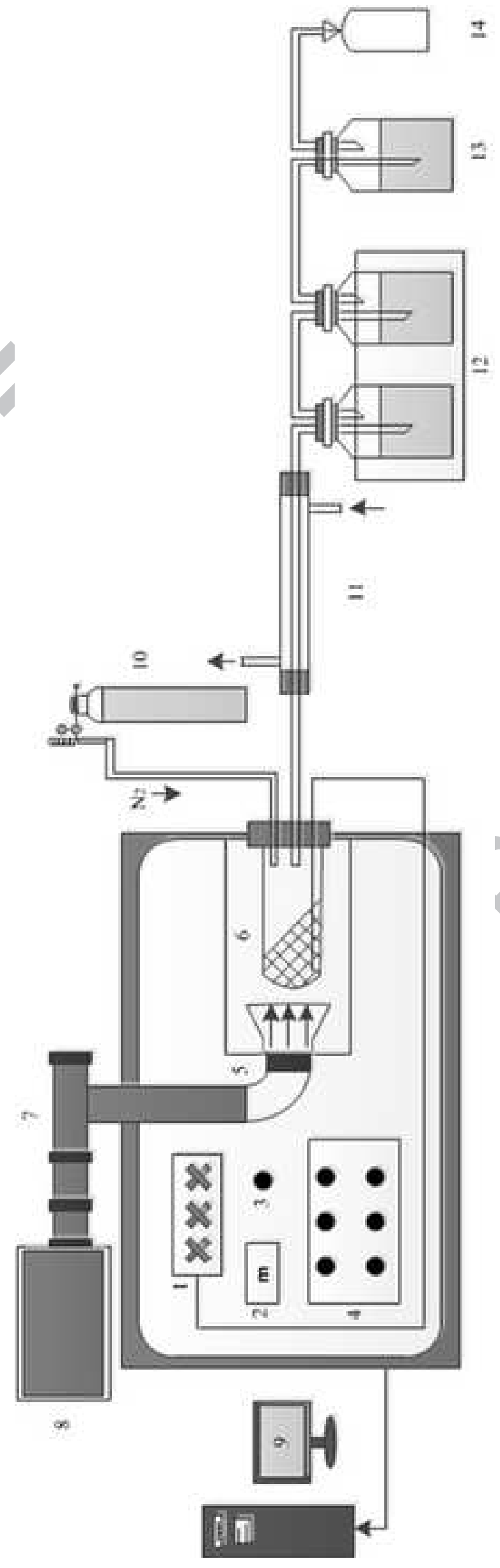




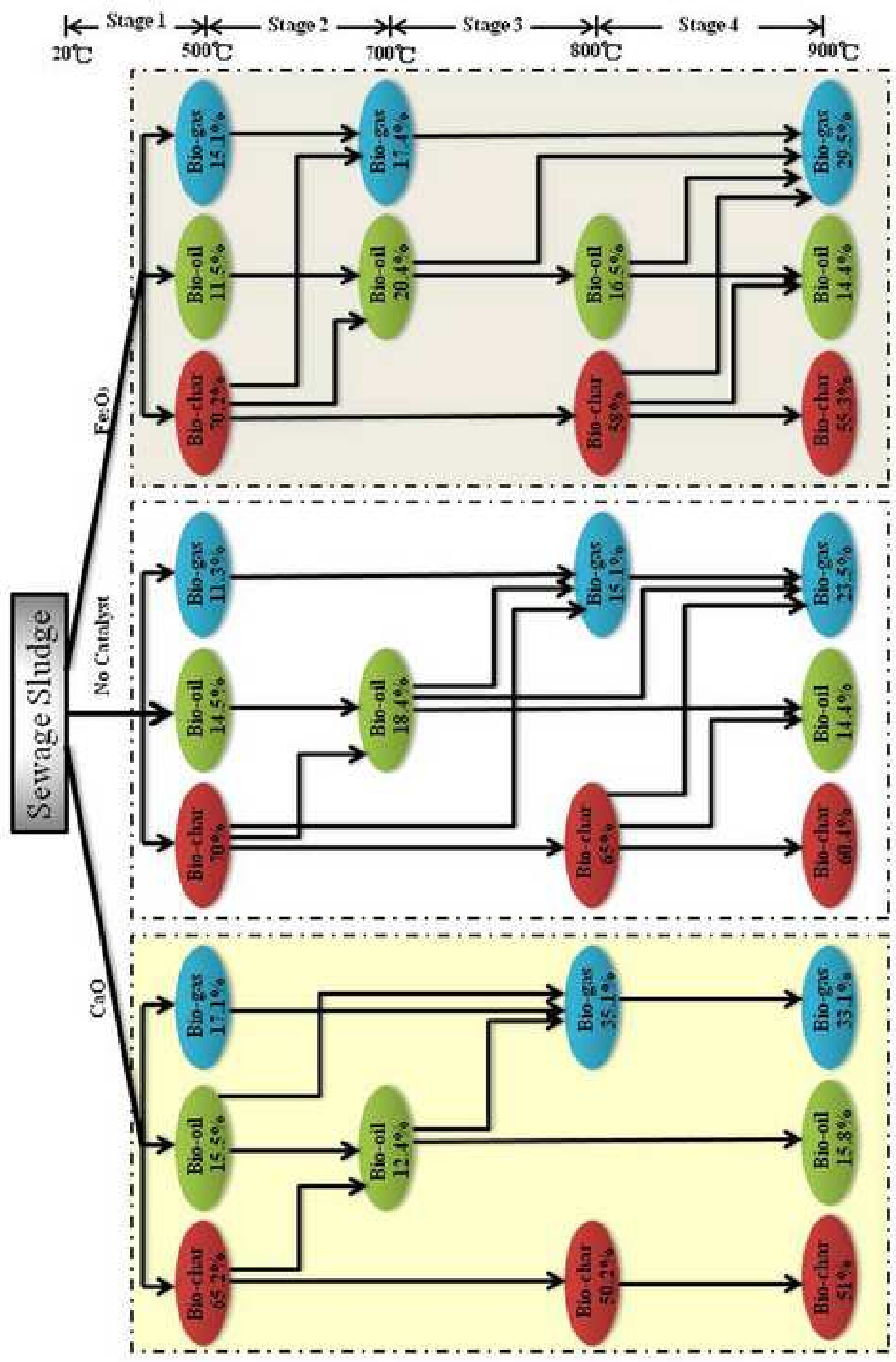



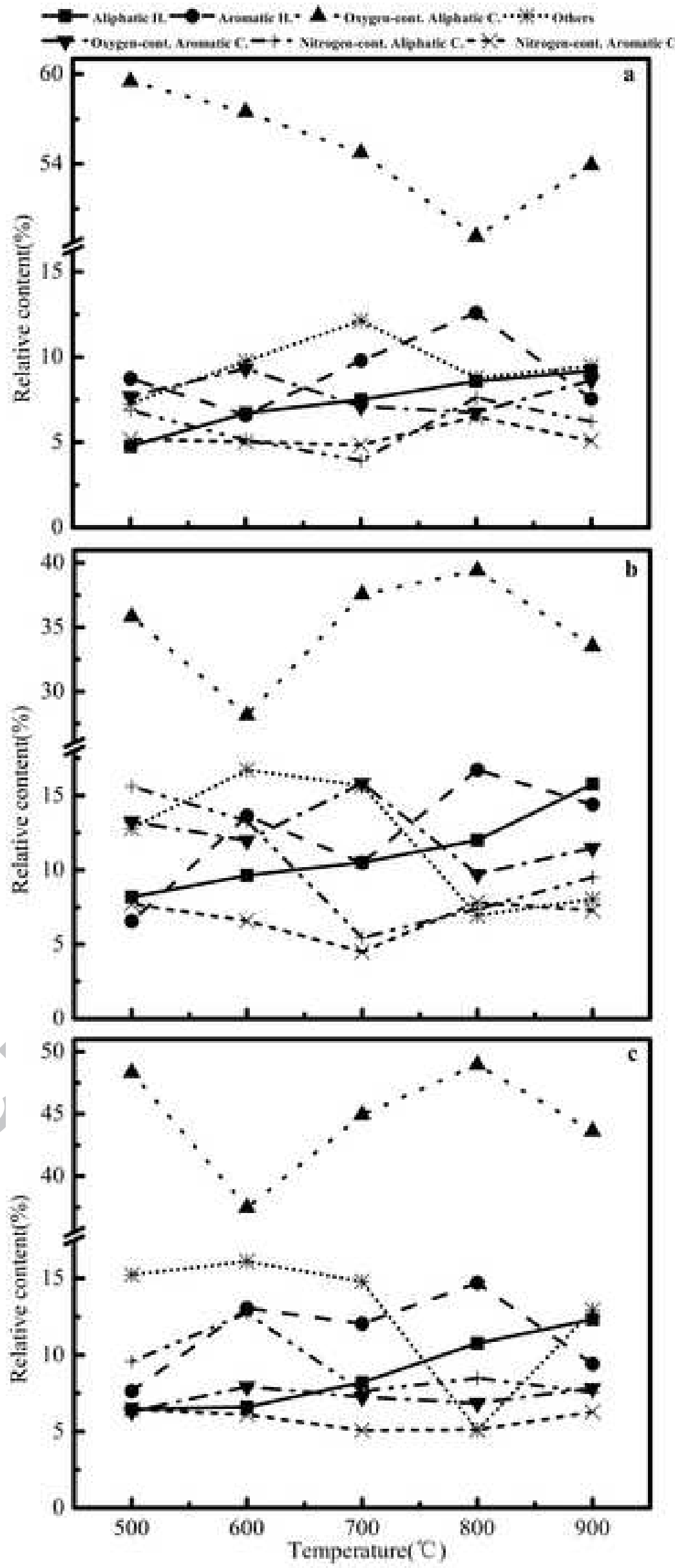

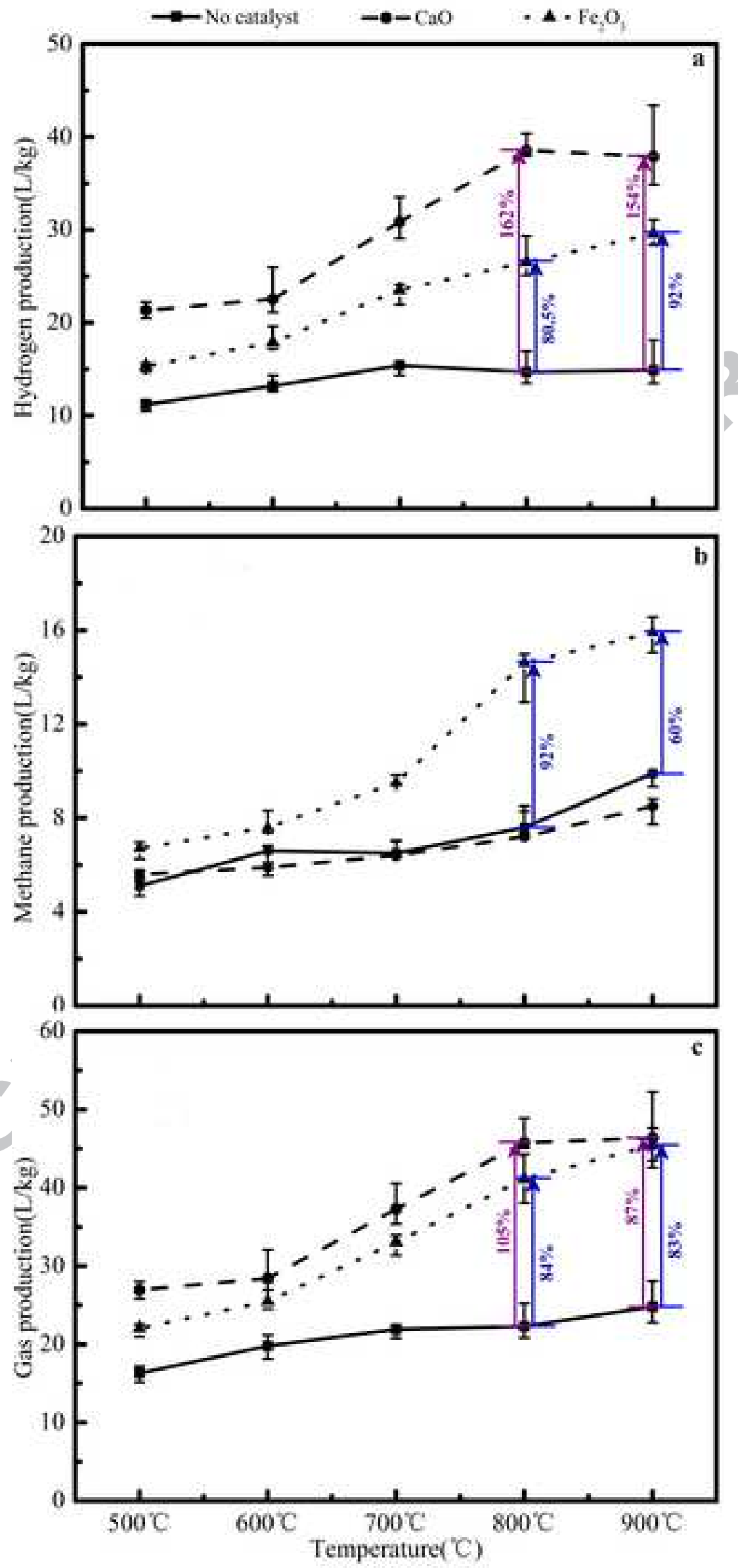

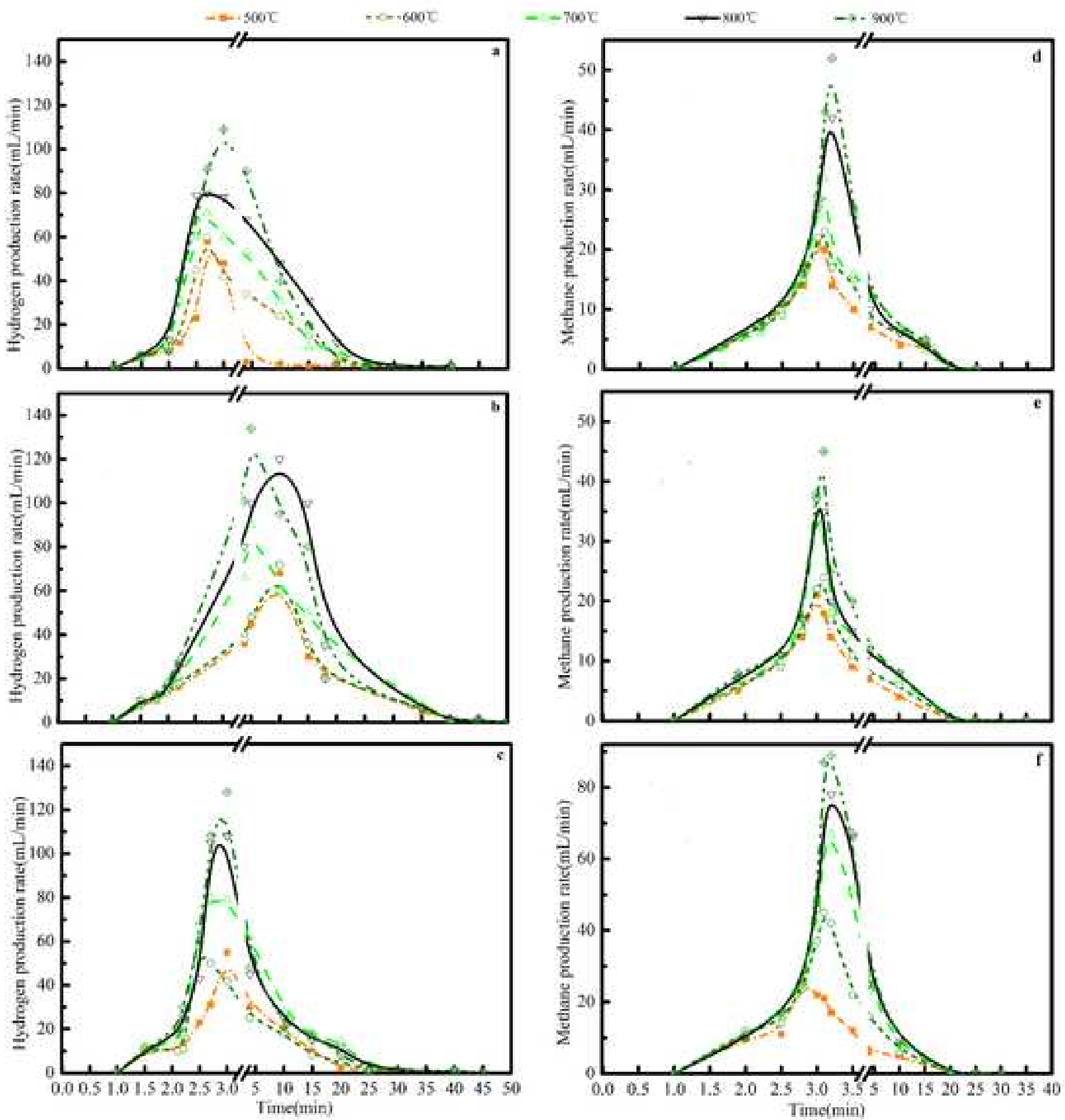


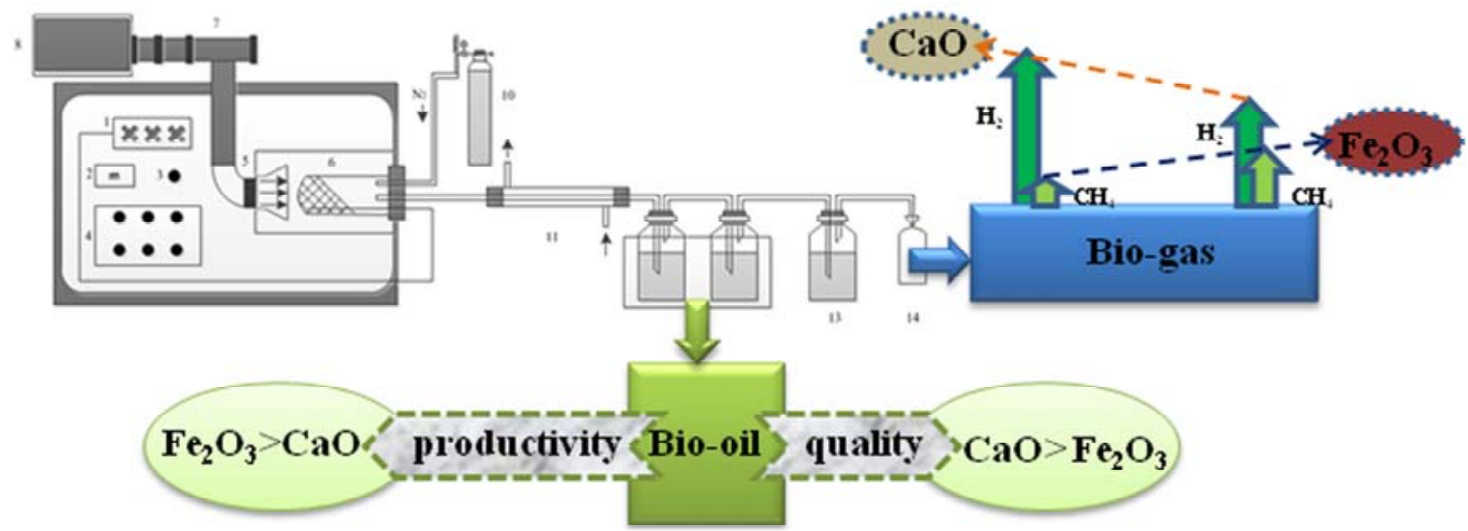

